\title{
Nephrogenic Adenoma
}

National Cancer Institute

\section{Source}

National Cancer Institute. Nephrogenic Adenoma. NCI Thesaurus. Code C7413.

So-called nephrogenic adenoma is a distinct metaplastic lesion of the urothelium characterized by aggregates of cuboidal or hobnail cells. These cells line thin papillary fronds on the surface or form tubular structures within the lamina propria. 